\title{
https://doi.org/10.46813/2021-136-075 \\ COMPARATIVE ANALYSIS OF ACCELERATION GRADIENTS FOR CHIP STRUCTURES WITH DIFFERENT REFRACTIVE INDICES
}

\author{
A.V. Vasyliev, O.O. Bolshov, O.O. Svistunov, A.I. Povrozin, V.P. Zaitsev, V.P. Leshchenko \\ G.V. Sotnikov \\ National Science Center "Kharkov Institute of Physics and Technology", Kharkiv, Ukraine \\ E-mail: o.bolshov@student.csn.khai.edu
}

The results of numerical studies of accelerating gradients in accelerators based on dielectric chip structures with different refractive indices, excited by a titanium-sapphire laser pulse, are presented. A comparative analysis of the influence of the refractive index on the rate of acceleration of electron bunches is carried out. Promising materials for the manufacture of dielectric laser accelerators are proposed.

PACS: 41.75.Jv, 41.75.Ht, 42.25.Bs

\section{INTRODUCTION}

Particle accelerators are an important tool in basic scientific research, industry and medicine. Traditional RF accelerators are often expensive and too large, which hinders their to be widespread, and their acceleration gradients are limited by the low breakdown threshold of the materials used and are usually equal to $20 \ldots 30 \mathrm{MeV} / \mathrm{m}$. In this regard, it became necessary to develop more compact and cheaper accelerators, which, in this case, would provide greater efficiency. One of such options is the concept of dielectric wakefield accelerators driven by a long sequence of electron bunches [1]. Another proposed by us turned out to be dielectric laser accelerators (DLA) based on chip structures, which will be considered in this work.

The dielectric structures used in such accelerators have a high damage threshold when operating in the optical range. Dielectrics have higher gradients due to the fact that they withstand fields exceeding $1 \mathrm{GV} / \mathrm{m}$ [2]. Due to advanced nanomanufacturing techniques, it has become possible to create precise and low-cost nanostructures from a variety of dielectric materials. In addition, they are transparent to the operating wavelengths of high-power and commercially available femtosecond laser systems. Thus, DLAs exhibit larger acceleration gradients than RF accelerators, are smaller and less expensive.

\section{ACCELERATION GRADIENT}

Following [2] give the expression for the acceleration gradient depending on the refractive index. To quantify DLA efficiency, an indicator such as the acceleration gradient $G_{a c c}$ is used, which is usually written as:

$$
G_{a c c}=\frac{1}{\lambda_{g}} \int_{0}^{\lambda_{g}} E_{z}(z(t), t) d z,
$$

where $\lambda_{g}$ is the grating period of the structure, $z$ is the direction of propagation of electrons, $E_{z}(z(t), t)$ is the longitudinal electric field. The acceleration gradient shows the electron energy gain per unit length and is usually measured in $\mathrm{MeV} / \mathrm{m}$.

Two other important indicators are:

1. The acceleration factor $f_{A}$ :

$$
f_{A}=\frac{G_{a c c}}{E_{0}}
$$

where $E_{0}$ is the input electric field inside the structure after Fresnel reflection at the interface between the two media. The acceleration coefficient is a dimensionless quantity that shows the efficiency of converting an incident electric field into an acceleration gradient.

2. The field enhancement factor $\eta$ :

$$
\eta=\frac{E_{\max }}{E_{0}},
$$

where $E_{\max }$ is the maximum electric field in the structure. This coefficient determines the ability of the structure to enhance the input field.

From equation:

$$
\frac{1}{2} \varepsilon_{0} E_{i n c}^{2}=\frac{1}{2} \varepsilon_{0} \varepsilon_{r} E_{0}^{2} \Rightarrow E_{0}=\frac{E_{i n c}}{n},
$$

where $E_{i n c}$ is the input electric field outside the structure, $n=\sqrt{\varepsilon_{r}}$ is the refractive index of the material; it follows that the acceleration gradient can be written as:

$$
G_{a c c}=\frac{\eta f_{A}}{n} E_{i n c}=\frac{\eta f_{A}}{n} \sqrt{\frac{2 F_{i n c}}{c \varepsilon_{0} \tau_{p}}},
$$

where $F_{\text {inc }}$ is the power density of laser radiation, $\tau_{p}$ is the pulse duration.

In Section 5, we will compare Eqs. (4) and (5) with the results of numerical simulation.

\section{MATERIAL SELECTION CRITERIA}

The material of the structure is an important component of the DLA and therefore some criteria should be followed when choosing it:

1. Transparency. The dielectric material must be transparent in the selected region of the laser spectrum. This is necessary to transfer maximum power to the accelerator and reduce material heating. Most dielectric materials are transparent to infrared radiation, so this criterion is not essential for the creation of DLA.

2. Laser-induced damage threshold (LIDT). From Eqn. (5) it follows that the acceleration gradient is proportional to the square root of the laser pulse power and, therefore, the maximum acceleration gradient is limited by the breakdown of the dielectric material. Thus, to obtain large acceleration gradients, materials should be used that will withstand high electric field strengths. It should also be taken into account that grating structures will be less durable than the bulk material [3]. 
3. Refractive index. DLA is an optical phase mask that modulates the amplitude and phase shift of electromagnetic waves when laser radiation is incident on the chip structure. Higher refractive indices give greater limiting of the electric field and create greater phase contrast.

It should be noted that since DLA operates in the reverse mode of Cherenkov radiation, for greater energy modulation, it is necessary to adhere to the rule that the electron velocity $\beta \mathrm{c}$ should be greater than the phase velocity of light in the material $c / n$, which means $n>1 / \beta$.

4. Simplicity of production. One of the conditions for synchronization between the first spatial harmonic and the electron bunch is that the period of the electrodynamic structure of the accelerator must satisfy the relation $\lambda_{g}=\beta \lambda$ [4], where $\lambda$ is the wavelength of laser radiation. That is, the grating period of the chip structure must be equal to the operating wavelength for relativistic electrons. Moreover, the production of such structures should be relatively quick and cheap.

5. Resistance to radiation of relativistic electrons. Materials such as Fused Silica, YAG, Lithium niobate and Sapphire are not damaged by relativistic electrons, while borosilicate glass (BK7) is.

\section{MATERIALS OVERVIEW}

Fused Silica was used in the first DLA demonstrations $[2,5]$. The material has a relatively high LIDT $2.1 \mathrm{~J} / \mathrm{cm}^{2}$ (at a wavelength $800 \mathrm{~nm}$, with a pulse duration of $30 \mathrm{fs}[6]$ ), and the methods of producing nanostructures from it are well studied [7 - 10]. In addition, as mentioned above, Fused Silica is resistant to electrons. One of the disadvantages of Fused Silica is its low refractive index 1.45 .

Recently, the production of DLA from Sapphire and Gallium Oxide has been demonstrated [11]. Both materials outperform Fused Silica in terms of LIDT and refractive index. Sapphire has a LIDT of $11 \mathrm{~J} / \mathrm{cm}^{2}$ $(800 \mathrm{~nm}, 100 \mathrm{fs})$ [12] and a refractive index of 1.76 . Gallium Oxide has, respectively, $2.6 \mathrm{~J} / \mathrm{cm}^{2}$ (760 nm, $9 \mathrm{fs}$ ) and a refractive index of 1.9 [13]. The main disadvantage of these materials is the complexity of manufacturing chip structures from them.

One of the materials mentioned that can withstand the high energies of relativistic electrons is Lithium niobate. This material is also interesting because it has the highest refractive index among those considered in this work, it is equal to 2.26. However, its LIDT is lower than that of the previous two materials, it is equal to $2.0 \mathrm{~J} / \mathrm{cm}^{2}[14]$.

The last material reviewed is the commercially available BK7 optical glass. In terms of refractive index, it is close to Fused Silica, it is equal to 1.51. But it has the lowest LIDT, only $2.55 \mathrm{~J} / \mathrm{cm}^{2}$ (760 nm, $200 \mathrm{fs}$ ) [15]. At the same time, as already noted, BK7 is destroyed by the radiation of relativistic electrons. Nevertheless, such material can be used in research in a number of cases, due to its availability.

Based on the works [16 - 18], for clarity, we introduce an equation for approximating the available data of LIDT of materials and reduce all values to the parame- ters of laser radiation equal to $800 \mathrm{~nm}$ wavelength and 120 fs pulse duration:

$$
\operatorname{LIDT}\left(\lambda_{2}, \tau_{2}\right) \approx \operatorname{LIDT}\left(\lambda_{1}, \tau_{1}\right) \times \frac{\lambda_{2}}{\lambda_{1}} \times \sqrt{\frac{\tau_{2}}{\tau_{1}}},
$$

where $\lambda_{1}$ and $\tau_{1}$ are the wavelength and duration of the pulse for the known LIDT, $\lambda_{2}$ and $\tau_{2}$ are the values of the determined LIDT (in our case, $800 \mathrm{~nm}$ and $120 \mathrm{fs}$ ).

All of these materials are transparent for a wavelength of $800 \mathrm{~nm}$ and have a low absorption index $\left(\sim 10^{-8} \ldots 10^{-7}\right)[19-24]$. For this reason, dielectric losses were not taken into account in the simulation.

The materials considered and their parameters are shown in Table 1.

DLA materials and their characteristics:

\begin{tabular}{|c|c|c|c|c|}
\hline Material & $\begin{array}{c}\text { LIDT } \\
\left(\mathrm{J} / \mathrm{cm}^{2}\right)\end{array}$ & $\begin{array}{c}\text { Approx. } \\
\text { LIDT } \\
\left(\mathrm{J} / \mathrm{cm}^{2}\right)\end{array}$ & $\begin{array}{c}\text { Refractive } \\
\text { index, } n\end{array}$ & $\begin{array}{c}\text { Trans- } \\
\text { mittance }\end{array}$ \\
\hline $\begin{array}{c}\text { Fused } \\
\text { Silica }\end{array}$ & 2.10 & 4.20 & 1.45 & 0.90 \\
\hline BK7 & 2.55 & 2.07 & 1.51 & 0.90 \\
\hline Sapphire & 11.00 & 12.05 & 1.76 & 0.85 \\
\hline $\begin{array}{c}\text { Gallium } \\
\text { oxide }\end{array}$ & 2.60 & 9.99 & 1.90 & 0.80 \\
\hline $\begin{array}{c}\text { Lithium } \\
\text { niobate }\end{array}$ & 2.00 & 3.43 & 2.26 & 0.75 \\
\hline
\end{tabular}

\section{SIMULATION AND RESULTS}

We used the particle-in-cell method to simulate DLA. A structure with a single grating was irradiated perpendicularly for transmission with a Gaussian pulse. The electron source was located at a height $\lambda / 2$ above the surface of the structure and emitted one electron bunch. The parameters of the chip structure, Gaussian pulse, and electron bunch are given in Table 2 .

Table 2

Parameters of the chip structure, Gaussian pulse, and electron bunch used in the numerical simulation

\begin{tabular}{|c|c|}
\hline \multicolumn{2}{|c|}{ Chip structure } \\
\hline Period, $\lambda_{g}$ & $800 \mathrm{~nm}$ \\
\hline Pillars height, $h$ & $400 \mathrm{~nm}$ \\
\hline Grooves width, $w$ & $400 \mathrm{~nm}$ \\
\hline \multicolumn{2}{|c|}{ Gaussian pulse } \\
\hline Center wavelength, $\lambda$ & $800 \mathrm{~nm}$ \\
\hline Pulse duration, $\tau_{p}$ & $120 \mathrm{fs}$ \\
\hline Beam waist, $w_{0}$ & $14 \mathrm{um}$ \\
\hline Electric field intensity, $E_{\text {inc }}$ & $1 \mathrm{GV} / \mathrm{m}$ \\
\hline Electron bunch \\
\hline Bunch width & $100 \mathrm{~nm}$ \\
\hline Electron energy & $50 \mathrm{MeV}$ \\
\hline Bunch length & $0.35 \mathrm{fs}$ \\
\hline
\end{tabular}

From the previously investigated profiles of chip structures [25], the profile of the "grooves" type was chosen as the main one for this work. The geometric image of the profile is shown in Fig. 1. Numerical modeling was carried out for all materials listed in Table 1. 


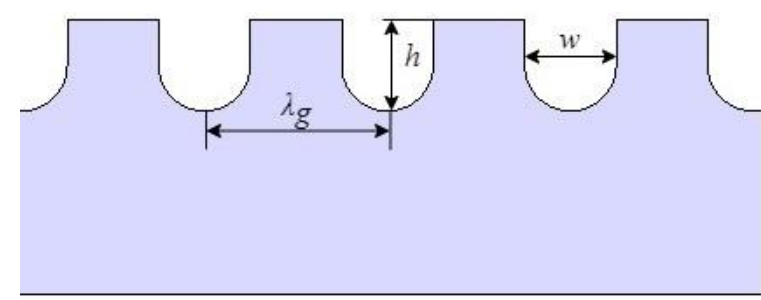

Fig. 1. Geometric image of profile of the used structure

Fig. 2 shows energy gain of the electrons depending on the longitudinal coordinate of electron propagation $z$ for different materials of chip structures. The figure shows that energy gain is proportional to the refractive index of the material.

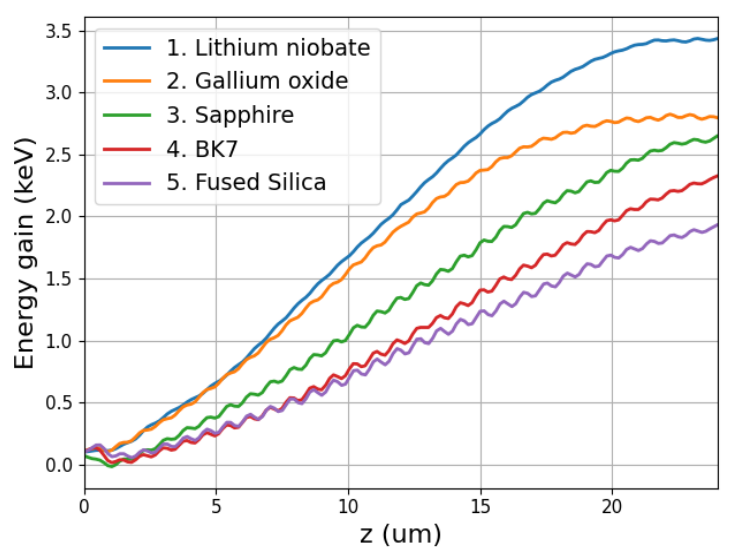

Fig. 2. Energy gain of the electrons for different materials of the accelerator

Fig. 3,a-c show the dependence of the electric field strength along the $z$ coordinate (accelerating channel). The blue curve indicates the distribution of the electric field at the time of the maximum intensity of the accelerating field when the electron is above the pillars of the chip structure, the red curve indicates the distribution of the field strength after half the optical period, during which the electron passes half the grating period and will be above the grooves. With an increase in the re- fractive index, the difference in intensity decreases. Thus, in the case of Fused Silica, although electrons experience a stronger accelerating field, they also experience a strong decelerating field after a time equal to the phase change in the $\lambda / 2$ interval. Whereas for Lithium niobate, due to the higher refractive index, the amplitude of the fields in the channel is less [see eqs. (4) and (5)], but the electron is in the accelerating phase throughout the entire path. As a result, Lithium niobate gives greater acceleration and a smoother curve in Fig. 2 (compared to Fused Silica curve). It follows from this that a more uniform electric field acts on the electron. Fig. 3,b shows an intermediate case that corresponds to the average refractive index of the selected materials (for Sapphire). In this case, the maximum intensity of the accelerating field is less than for the case with Fused Silica. However, when the phase changes by $\lambda / 2$, the electron is still affected by the decelerating field, which is why the total acceleration gradient is lower than for the case with Lithium niobate.

Fig. 3,d-f show the distribution of the longitudinal electric field at the moment of maximum intensity at the height of the flight of electrons. Red color corresponds to the accelerating field, blue one to the decelerating. The presented figures clearly show how the refractive index of the structure affects the formation of the longitudinal accelerating component of the electric field in space. In Fig. 3,d field has a more uniform distribution throughout the entire flight of electrons. It can be seen that for materials with a higher refractive index (Fig. 3,e,f), the field modulation becomes more pronounced. When the wave phase changes in the $\lambda / 2$ interval, the field will change to a decelerating one and the electrons located above the grooves will be affected by the decelerating field, the stronger the lower the refractive index of the material. Consequently, the most advantageous in this case will be a material that, due to its refractive index, makes it possible to change the field to an accelerating one.

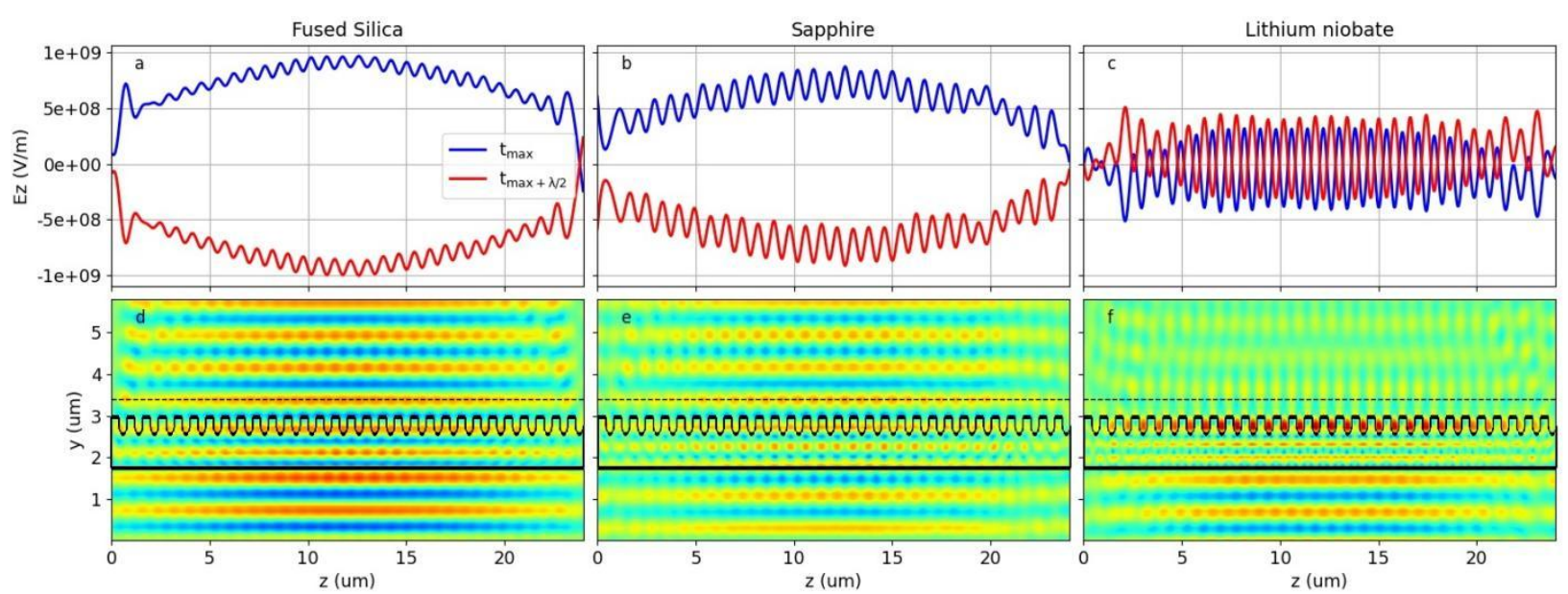

Fig. 3. Electric field intensity along the propagation of electrons for various materials $(a-c)$, distribution of electric fields formed by the chip structure in accordance with a-c (d-f).

The dotted line indicates the height of the flight of electrons $\lambda / 2$

Table 3 shows the acceleration gradients obtained at modeling for various materials, as well as the ratio of refractive indices and acceleration gradients with those of Fused Silica, the main material used in DLA. 
Table 3

Refractive indices and acceleration gradients of various materials, and the ratio of these parameters to those of Fused Silica

\begin{tabular}{|c|c|c|c|c|}
\hline Material & $\begin{array}{c}\text { Refrac- } \\
\text { tive } \\
\text { index }\end{array}$ & $\begin{array}{c}\text { Acceleration } \\
\text { gradient, } \\
(\mathrm{MeV} / \mathrm{m})\end{array}$ & $\begin{array}{c}\text { Fused } \\
\text { Silica } \\
\text { refractive } \\
\text { index ratio }\end{array}$ & $\begin{array}{c}\text { Fused } \\
\text { Silica } \\
\text { gradient } \\
\text { ratio }\end{array}$ \\
\hline $\begin{array}{c}\text { Fused } \\
\text { Silica }\end{array}$ & 1.45 & 73.7 & 1.00 & 1.00 \\
\hline BK7 & 1.51 & 92.5 & 1.04 & 1.26 \\
\hline Sapphire & 1.76 & 102.9 & 1.21 & 1.40 \\
\hline $\begin{array}{c}\text { Gallium } \\
\text { oxide }\end{array}$ & 1.90 & 113.3 & 1.31 & 1.54 \\
\hline $\begin{array}{c}\text { Lithium } \\
\text { niobate }\end{array}$ & 2.26 & 140.4 & 1.56 & 1.91 \\
\hline
\end{tabular}

Simulation results and material characterization indicate that Sapphire, Gallium oxide and Lithium niobate are promising candidates as primary materials for DLA research.

\section{CONCLUSIONS}

In this paper, various criteria that are desirable to consider when choosing a material for DLA were described, and materials common in research were considered, as well as those that have more preferred characteristics.

Simulation of the acceleration of electrons was carried out using the considered materials as the material of the dielectric structure.

The results obtained showed the increase of the energy gain of the accelerated electron bunch with an increase in the refractive index. At the same time, as follows from expressions (4) and (5), the amplitude of the longitudinal electric field decreases with an increase in the refractive index. But the integral effect during the motion of the accelerated bunch along the structure consists in an increase in its energy gain, since for half the period of the structure, the bunch is in a weaker decelerating field with an increase in the refractive index. Moreover, for some materials, the bunch can be in the accelerating phase throughout the entire period of the structure, which can lead to an even greater energy gain.

Sapphire, Gallium oxide and Lithium niobate have been identified as promising materials for future DLA research.

\section{ACKNOWLEDGEMENTS}

Work supported by The National Research Foundation of Ukraine, program "Leading and Young Scientists Research Support" (project \# 2020.02/0299).

\section{REFERENCES}

1. I.N. Onishchenko et al. Concept of dielectric wakefield accelerator driven by a long sequence of electron bunches // Proc. IPAC. 2013, p. 1259.

2. E.A. Peralta et al. Demonstration of electron acceleration in a laser-driven dielectric microstructure // Nature. 2013, 503, 7474, p. 91-94.

3. K. Soong et al. Experimental determination of damage threshold characteristics of IR compatible opti- cal materials // Particle Accelerator Conference Proceedings. 2011, v. 277.

4. T. Plettner, R.L. Byer, and B. Montazeri. Electromagnetic forces in the vacuum region of laser-driven layered grating structures // Journal of Modern Optics. 2011, v. 58.17, p. 1518-1528.

5. J. Breuer, P. Hommelhoff. Laser-based acceleration of nonrelativistic electrons at a dielectric structure // Physical review letters. 2013, v. 111.13, p. 134803.

6. S.Z. Xu et al. Experimental study on $800 \mathrm{~nm}$ femtosecond laser ablation of fused silica in air and vacuum // Nuclear Instruments and Methods in Physics Research Section B: Beam Interactions with Materials and Atoms. 2016, v. 385, p. 46-50.

7. V.M. Donnelly, A. Kornblit. Plasma etching: Yesterday, today, and tomorrow // Journal of Vacuum Science and Technology A: Vacuum, Surfaces, and Films. 2013, v. 31.5, p. 050825.

8. C.J. Mogab, A.C. Adams, and D.L. Flamm. Plasma etching of $\mathrm{Si}$ and $\mathrm{SiO}_{2}$. The effect of oxygen additions to $\mathrm{CF}_{4}$ plasmas // Journal of Applied Physics. 1978, 49.7, p. 3796-3803.

9. B. Wang et al. Polarizing beam splitter of a deepetched fused-silica grating // Optics Letters. 2007, v. 32.10, p. 1299-1301.

10. Leech, P. W. Reactive ion etching of quartz and silica-based glasses in CF4/CHF3 plasmas // Vacuum. 1999, v. 55.3-4, p. 191-196.

11.H. Deng. Novel materials and nanofabrication methods for the dielectric laser accelerator (DLA). Stanford University, 2018.

12. O. Uteza et al. Laser-induced damage threshold of sapphire in nanosecond, picosecond and femtosecond regimes // Applied Surface Science. 2007, v. 254.4 , p. $799-803$.

13. B.E. Harris. Few cycle pulse laser induced damage studies of gallium oxide and gallium nitride: Diss. The Ohio State University, 2019.

14. Q. Meng, et al. Damage threshold of lithium niobate crystal under single and multiple femtosecond laser pulses: theoretical and experimental study // Applied Physics A. 2016, v. 122.6, p. 582.

15. A.Ben-Yakar, and R.L. Byer. Femtosecond laser ablation properties of borosilicate glass // Journal of Applied Physics. 2004, v. 96.9, p. 5316-5323.

16. F. Rainer, W.H. Lowdermilk, and D. Milam. Bulk and surface damage thresholds of crystals and glasses at $248 \mathrm{~nm} / /$ Optical Engineering. 1983, v. 22.4, p. 224431 .

17. Arlee V. Smith, Binh T. Do. Bulk and surface laser damage of silica by picosecond and nanosecond pulses at $1064 \mathrm{~nm} / /$ Applied Optics. 2008, 47.26, p. 4812-4832.

18. B.C. Stuart et al. Nanosecond-to-femtosecond laserinduced breakdown in dielectrics // Physical Review B. 1996, v. 53.4, p. 1749.

19. R. Kitamura, L. Pilon, and M. Jonasz. Optical constants of silica glass from extreme ultraviolet to far infrared at near room temperature // Applied Optics. 2007, v. 46.33, p. 8118-8133.

20. R.H. French, H. Müllejans, and D.J. Jones. Optical properties of aluminum oxide: determined from vacuum ultraviolet and electron energy loss spectrosco- 
pies // Journal of the American Ceramic Society. 1998, v. 81.10, p. 2549-2557.

21. A.K. Harman, S. Ninomiya, and S. Adachi. Optical constants of sapphire $\left(\alpha-\mathrm{Al}_{2} \mathrm{O}_{3}\right)$ single crystals // Journal of Applied Physics. 1994, v. 76.12, p. 80328036.

22. K.A. Mengle et al. First-principles calculations of the near-edge optical properties of $\beta-\mathrm{Ga}_{2} \mathrm{O}_{3} / / \mathrm{Ap}$ plied Physics Letters. 2016, v. 109.21, p. 212104.

23. H. Peelaers, C.G. Van de Walle. Sub-band-gap absorption in $\mathrm{Ga}_{2} \mathrm{O}_{3} / /$ Applied Physics Letters. 2017, v. 111.18, p. 182104.
24. M. Leidinger et al. Comparative study on three highly sensitive absorption measurement techniques characterizing lithium niobate over its entire transparent spectral range // Optics Express. 2015, v. 23.17 , p. $21690-21705$

25. A.V. Vasyliev et al. Influence of the Profile of the Dielectric Structure on the Electric Fields Excited by a Laser in Dielectric Accelerators Based on Chip // IPAC21. 2021, TUPAB247.

Article received 07.10.2021

\section{СРАВНИТЕЛЬНЫЙ АНАЛИЗ ГРАДИЕНТОВ УСКОРЕНИЯ ДЛЯ ЧИП-СТРУКТУР С РАЗЛИЧНЫМИ ПОКАЗАТЕЛЯМИ ПРЕЛОМЛЕНИЯ}

А.В. Васильев, А.О. Больщов, О.А. Свистунов, А.И. Поврозин, В.П. Зайцев, В.П. Лещенко, Г.В. Сотников

Представлены результаты численных исследований ускоряющих градиентов в ускорителях на основе диэлектрических ЧИП-структур с различными показателями преломления, возбуждаемых титан-сапфировым лазерным импульсом. Проведен сравнительный анализ влияния показателя преломления на темп ускорения электронных сгустков. Предложены перспективные материалы для изготовления диэлектрических лазерных ускорителей.

\section{ПОРІВНЯЛЬНИЙ АНАЛІЗ ГРАДІЕНТІВ ПРИСКОРЕННЯ ДЛЯ ЧІП-СТРУКТУР З РІЗНИМИ ПОКАЗНИКАМИ ЗАЛОМЛЕННЯ}

\section{А.В. Васильєв, О.О. Больиов, О.О. Свістунов, А.І. Поврозін, В.П. Зайцев, В.П. Лещенко, Г.В. Сотніков}

Представлені результати чисельних досліджень прискорюючих градієнтів у прискорювачах на основі діелектричних ЧІП-структур з різними показниками заломлення, збуджуваних титан-сапфіровим лазерним імпульсом. Проведено порівняльний аналіз впливу показника заломлення на темп прискорення електронних згустків. Запропоновано перспективні матеріали для виготовлення діелектричних лазерних прискорювачів. 